\title{
Bulgarian Intellectuals and Students and Their Notion of the Age of Socialism
}

\author{
Iskra Baeva \\ Sofia University “St. Kliment Ohridski”, Sofia, Bulgaria
}

\begin{abstract}
In the years of the Bulgarian transition from Soviet-style state socialism to parliamentary democracy and market economy, the notions of the recent past experience profound changes. This process is predetermined by the new political imperative - the need to reorient the country from the Eastern bloc to the Western world. Changing the attitude of the Bulgarian society towards the socialist past is accomplished first through the change of curricula and textbooks, but also with the help of the media, which give floor to critics of socialism. Over time, however, especially since the neo-liberal economic transformations that took place under the so-called Washington Consensus led to deindustrialisation and high unemployment, a change in social attitude towards socialism began. In the 21 st century, the attitude towards socialism changed. The total denial that prevailed in the 1990s gave way to a more nuanced picture-alongside the shortcomings and crimes, there are also talks about positive features of socialism such as social security and stability. This is evident both in the positions of the Bulgarian intellectuals and in the views of Bulgarian students about the socialist past.
\end{abstract}

Keywords: transition to democracy, state socialism, memoirs, student questionnaires, textbooks

\section{Introduction}

In the autumn of this year, all Eastern Europe is celebrating the 29th anniversary of the start of the events that led to the collapse of the system of state socialism transferred to the region by the Soviet Union after the World War Two and surviving for four and a half decades. At the same time, Europe and the world celebrate the end of the Cold War and the beginning of the new era in which we live and which has proved to be no less full of contradictions, conflicts, and wars. The difference in the manner in which we celebrate the anniversary of the 1989 Revolutionary Autumn in Eastern and Western Europe shows that there still exists, though not so apparently, a border between the two postwar worlds - one of them facing the major problems of post-socialist transformations, while the other is fighting the new challenges parliamentary democracy—nationalism and populism.

The anniversary is a suitable time for looking back on the most recent past, for a more unemotional assessment of the system under which two generations of Eastern Europeans lived and with the consequences of which another generation, today's youth, still lives. The available records of that age enable us to recall the most recent past. Another favourable circumstance is the already established parliamentary democracy and market economy which create a new scale of comparison with the socialist system that collapsed almost three decades ago. Because of this last fact, the comparison can extend beyond the political imperative of the initial

Iskra Baeva, Ph.D., Prof., Faculty of History, Sofia University “St. KlimentOhridski”. 
years and escape the ideologization of history. I will try to make a comparison between the present and the past based on data, information, and materials that give examples of "wrong" and "right" in socialism.

Of course I am aware that any attempt to outline the "human" parameters of socialism - in other words, the recognition of its "bad" and "good" characteristics by particular citizens - would be quite biased. However, unlike most historical and social analyses, in this case the subjective recognition of the past is not an obstacle; on the contrary-it was my object. Recalling such a complicated age that has been so oversimplified after its collapse should not be done by using the average statistical data. My attention will focus on the personal interpretations of our one-sided and scarce recent past, which follow the principle of comparison-with our colourful democratic and consumer present.

\section{Changes in the Interpretation of the Socialist Era}

I will start with a few words of the evolution which the interpretation of the socialist era went through. The shift in historical science started a bit later after the beginning of changes. Contrary to most other socialist countries in Eastern Europe, in the case of Bulgaria, the changes were not a result of a kind of "people's revolution"; they were rather "a palace coup" whereby pro-Gorbachev group in the Political Bureau of the Central Committee of the Bulgarian Communist Party forced Todor Zhivkov to resign (Baeva, 2006, pp. 45-52; Трайков, 1999), hence the process developed slower. Nevertheless, the new interpretation of the recent past started as an absolutely negative one-all newspapers ${ }^{1}$ were full of all that stuff about repressions and misuses of power by Zhivkov "and his circle". And all these materials became the focus of the revived opposition press.

\section{The New Wave of Memoirs}

The prevailing negation of the collapsed system left its mark on the first wave of recollections of the age of socialism. The picture of socialism was gloomiest in the memories of those repressed (Бочев, 1990; Минков, 1990; Бончева, 1991; Христов, 1991; Гешев, 1992; Генов, 1993; Василев, 1995; Огойски, 1995; Дертлиев, 1996). However, similar tendency could be found in the first memoirs of the representatives of the former regime as well (Живков, 1991; Михайлов, 1993; Солаков, 1993; Иванов, 1994). One of the most typical examples of the then approach was the book by one of Zhivkov's economic advisors, Kostadin Chakurov (Чакъров, 1990), which made a stir in 1990. In it he gave detailed proofs of his thesis that Todor Zhivkov had been a secret collaborator of the pre-war police chief, Nikola Geshev, and provided much information about wrong economic decisions. Though in a different way and by pointing out different disadvantages, the whole first wave of memoirs depicted socialism as an age full of repressions, crimes, betrayals, misunderstandings, or simply stupid decisions.

In a very short time, however, it arose the second wave of memoir interpretations of socialism, characterized by an attempt to represent the recent past as a combination between "wrong" and "right". Logically, the thesis that not everything in socialism had been wrong was launched by the person most attacked after 10 November 1989, Todor Zhivkov. Contrary to most of his former collaborators, he needn't take into consideration the new theses - posters with the picture of Zhivkov behind bars, demanding that he should be brought to trial appeared at the very first opposition meeting on 18 November 1989. Since he could no longer appeal to people by laying the blame for "the wrong" on others, Zhivkov decided "to row against the tide" of

\footnotetext{
${ }^{1}$ In February 1990, the newspaper of the Social-Democrats-"Svoboden narod" appeared again, followed by the newspaper of the new oppositional force UDF-"Democracia", whose chief editor was Yordan Vassilev, a writer and art critic.
} 
mass feelings and started defending his government, cleverly identifying it with everything positive achieved throughout the post-war period. He began in 1990 with interviews and letters to the media and his controversial book, Against Some Lies, was published in 1993 (Живков, 1993). Being a skilled demagogue, Zhivkov felt that the high social price of economic reforms would gradually displace the political rejection of the regime and would breed nostalgia for the security under socialism. And he seized the opportunity. While his case was still under investigation in 1991, Zhivkov made the statement that he was ready to take the responsibility for what had happened during socialism—but taking "the bad" with "the good".

The third memoir wave of memoirs arose in the context of new adjustments and found expression in an impressive series of books by former communist functionaries (Аврамов, 1993; Тодоров, 1995; Семерджиев, 1999; Бонев, 2001). In their memories, those party workers followed the example of Todor Zhivkov, defending their life paths and emphasizing the advantages of life under socialism in comparison to capitalism that was gaining ground in Bulgaria. And again, the most typical example of that memoir wave gave the new book by Kostadin Chakurov, From the Second Floor to the Invasion of Democrats (Чакъров, 2001). A decade after trying to discredit Zhivkov with his first book, in his second one, Chakurov declared him not guilty and accused his inter-party opponents, Andrey Lukanov and Peter Mladenov, of betrayal and destruction of socialism. The sharp change in the stands of the popular writer demonstrated mainly the changed public feelings and the desire of many active public figures to be in agreement with the opinions prevailing at that moment.

The evolution in memoir literature shows that with the crucial 1989 year becoming a thing of the past, the memory of socialism in Bulgaria grew detached and independent from the reality prior to 1989. Personal experiences were now a distant memory, a blur transformed depending on the influence of the new conditions. Particular recollections were replaced by a generalized memory, in which the idea of socialism was refracted through the prism of the transition's political and economic conditions. And as they were changing rapidly, the recollecting of socialism continued its evolution. The new notion of socialism formed as a complex mixture of different, often opposite, memories of the elderly, of life hardships, successes, and failures the middle-aged faced, while the family memory, the educational programs, and the media played a major role for the younger generation. The image is not uniform in neither of its components; the idea of socialism is complicated and multiform, and yet it can be generalized.

\section{Changes in Public Attitudes}

I will try to trace out how society has changed its attitude towards socialism in the years of transition and what the notion of it is on the eve of the 30th anniversary of the beginning of the transition. For that purpose, I will rely on sociological studies that show how today's Bulgarians from different generations remember the age of socialism, on my questionnaires completed by students and on statements made in the media by public figures from different spheres. The focus of my attention is the notion of the negative and positive aspects of the recent past.

The views of young Bulgarians from the generation that grew up and was educated in the years of transition are the most interesting ones concerning this subject. They do not have their own memories of socialism; therefore their idea reflects the general feelings, what they have heard in the family environment, at school and from different media. Youth notion points mainly to the state of the contemporary Bulgarian society. 
Memoir literature affects least the public feelings about socialism, whether it presents socialism in a negative light or tries to balance between the bad and the good. The reason is that book reading in the years of transition dropped sharply and memoirs were published in a small number of copies by small publishers.

\section{The Role of Textbooks}

The second factor that forms the young Bulgarians' idea of socialism is the educational system. At school, the age of socialism is presented in the classes in history, literature and, to some extent, in geography. The great importance of education was recognized right from the start of the transition, so the new political powers initiated changes in the educational programs. Teachers were the first ones to support all together the aspiration for democracy. It must be taken into consideration that the attitude towards socialism changed prior to the beginning of the transition due to the profound impact of the Soviet perestroika in Bulgaria through the direct broadcasting of Soviet television and the mass subscription to the Soviet press. The influence of the Soviet press and television is great, as Bulgarians study Russian language at school, but also because two languages are Slavic, and the Cyrillic alphabet coming from Bulgaria is used in the Soviet Union. A procedure for writing new textbooks was initiated in 1988 and they were published at the beginning of the transition (Трифонов, 1991; Мирчева, Найденов, \& Баева, 1991). The attitude towards socialism expressed in these textbooks was critical, though it was not totally rejected.

With the transition entering on the crucial phase of the transition - when the new political powers won the elections on 13 October 1991-a fundamental change was made to the syllabuses. In the middle of the 1991/1992 school year Nikolay Vassilev, Minister of Education in the first government of the UDF and a former dissident, withdrew from circulation all history textbooks.He assigned historians, renowned for their anticommunist positions, the task to write new texts in Bulgarian and world history (Петков, 1992; 1993; Бобев, 1992; Семков, 1992; Ангелов, Георгиева, Бакалов, \& Цанев, 1992). They were hurriedly written and did not meet the textbook requirements, so they were termed Notes and their main aim was to give a new anticommunist interpretation of history. Interestingly, the postwar period, which was in the center of memoir and publicity negation of the early period of the transition, was not presented at all in these textbooks ${ }^{2}$.

Socialism was not included in the syllabuses till the mid-1990s when the political situation changed-the $\mathrm{BCP}$ returned to power. It was the first time when the Ministry of Education led by the history professor, Ilcho Dimitrov, approved new history textbooks that encompassed the whole postwar period. Besides, this was the first time when an alternative in writing textbooks was given and as a result, Bulgarian school was offered three textbooks that acquainted pupils with the whole span of Bulgarian history (Гюзелев, Косев, Лалков, Огнянов, Радева, 2001; Делев, Ангелов, Бакалов, Георгиева, Митев, Трифонов, Баева, Василева, \& Калинова, 2001; Фол, Мутафчиева, Гаврилова, \& Илчев, 2001). In those first textbooks of the transitional years, covering the period of socialism as well, the authors were absolutely free to interpret facts; hence the texts conveyed different opinions. The negative attitude towards the system that was dominant until recently was quite common but mainly with respect to its political characteristics. There were differences in the presentation of social and economic transformations - they were also criticized as a transfer of the Soviet model, but some textbooks spoke positively of industrialization and of the general economic, social, and cultural development.

${ }^{2}$ This approach was preserved in the other textbook of the same author: Милен Семков, История. 10 клас (Milen Semkov, History for 10th Grade) (Свят-Наука, 1995; 2001). 
The last wave of new textbooks emerged at the beginning of the new century under the right-wing government of Ivan Kostov. As the instructions of the Ministry of Education led by the historian Vesselin Metodiev show, it was not only compulsory to include the term "totalitarianism", but also to repudiate squarely socialism as a system. In defiance of the strict instructions, the new textbooks intensified the differences in the interpretation of socialism ${ }^{3}$, possibly because after the first decade of transition, the public attitude towards socialism was no longer as unanimously negative as it was at the beginning.

Judging by what is written in history textbooks, young Bulgarians' attitude towards socialism should be negative. But the impact of school on the contemporary notion of socialism should not be magnified, since textbook interpretations hardly ever touch young Bulgarians. The explanation is that the educational process hardly ever touches the study of socialism because tuition in high schools is orientated to the preparation of pupils for entrance to universities and usually the entrance exam synopses cover only the period till the end of the World War One ${ }^{4}$. In this situation, teachers prefer to teach history till that period, thus avoiding the danger of founding their interpretations of modern Bulgarian history in conflict with the changing political adjustments. In fact, Bulgarian school of the early 21st century refuses to give young Bulgarians knowledge of the events of almost the entire 20th century.

\section{The Role of Mass-Media}

The third factor that forms the notion of socialism in Bulgarians who do not have their own personal memories is the statements made by popular public figures and launched in the media.

The media environment has changed radically through the years of transition. Variety has replaced the officious press, the only state-owned radio and television which presented the developments in Bulgaria and around the world one-sidedly. The new media such as newspapers, radio stations, and televisions are supplemented with electronic newspapers, magazines, and sites and everyone is free to express their opinions in the Internet forums. Variety is one of the great achievements of the transition but is accompanied by the waning impact of the statements touching much fewer people than under socialism. This side effect of pluralism and democracy affects mostly the intellectuals who were used to have their messages followed closely and taken as a moral imperative (Тодоров, 1998, pp. 140). That's why it was the so-called artistic and creative intelligentsia who first outlined the advantages and disadvantages of democracy, comparing it with the good and the bad of the age of socialism.

\section{Intellectuals About Socialism and Transition}

All intellectuals without exception define censorship as the worst thing under socialism. I will cite two statements made by popular persons of the years of socialism. The first one is the poet Georgi Konstantinov, accused of dissident activity by the authorities in 1988 (Дума, March 1, 2004). Artists and musicians also remember incriminated works. In 2009, one of the sculptors most rewarded under socialism, Velichko Minekov tells of such an episode of the past (Tpyd, July 3, 2009). One of the most popular composers, Stefan Dimitrov,

\footnotetext{
${ }^{3}$ The 11 th grade textbooks, introduced in schools in 2002/2003, were four in number, published by Prosveta, Planeta 3, Anubis, Slovo. The authors were once again university professors and academic researchers, but besides a team from the Sofia University "St. Kliment Ohridski" there was one from University of Veliko Tarnovo "St. St. Cyril and Methodius".

${ }^{4}$ The media gave floor to a discussion about the hronological scope of history teaching, but those, who insisted that the whole socialist period as well as the transition years should be included in teaching, were only few. Iskra Baeva, "Glednata tochka na politicite i istoriata", Trud, April 26, 1998; 24 chasa, July 24, 2001.
} 
tells about the absurdities of censorship (Tpyd, July 31, 2009).

Examples of the restrictions on art are a countless number since they affect the whole society. They apply to historical studies too, as shown by the comparison between what was written prior to and after November 10, 1989. An example of this is the books of Lubomir Ognyanov (Гаук, Яковлев, Малиа, Лаар, Шарланов, Огнянов, Цветков, Рушан, Нойберт, Янакакис, \& Байе, 2004, pp. 293-347). The same is true of the works dedicated to Georgi Dimitrov, written by Milen Semkov, or of the studies on the period from 1944 to 1948 conducted by Mito Isusov. The above mentioned books were published at different times and therefore it is more difficult to compare them; however, a wonderful opportunity for comparison gives the book by the art critic Dimitar Avramov, The Annals of a Dramatic Decade. Bulgarian Art Between 1955-1965 (Аврамов, 1994). Dimitar Avramov describes the censorship but also demonstrates such sharp means of expression that contrast with the mild tone and the ambition to explain the age in the main study (Аврамов, 1994, pp. 413-420, pp. 420-428). Shifting of accents - from explanation to condemnation-is typical of the interpretation of socialism in the first half of the 1990s and is still found in the anticommunist approach to this day.

Reflections on socialism are not an end in themselves; they emerge in the course of comparison with the new value system established in the years of transition. Again, the representatives of intellectuals are unanimously critical of the power of money and consumerism. According to writer Georgi Konstantinov, "the ideological pressure was replaced by the conjuncture of market economy". Similar feelings have the poet Kalin Donkov, "society today does not offer us values" (Tpyd, October 21, 2008). Both of them are of the older generation and their discontent seems natural, but one of the most successful young Bulgarian writers, Alec Popov, is critical of the present too. He states that

with the fall of the ideological censorship, society was given a chance to make up for many things. At the same time, many cultural institutions were broken, as it was with book publishing... Culture is still approached in a utilitarian way and a certain ad hoc cause is served. (Новинар, June 24, 2006)

Journalists are the second critical group; their influence in the years of transition grew and went beyond the influence of writers. Philip Panayotov, veteran journalist and professor of history of Bulgarian journalism, describes the faults of modern journalism: “There is some irresponsibility in today's Bulgarian journalism, huge one. But it is also related to the lack of a social cause". The cool upholder of democracy and a professor of linguistics, Vladko Murdarov, exclaims,

once they arrested you for free thinking and sent you to a camp, now they fire you, give you "a discharge note" and you will never find work in the respective field... we've become such slaves of customs that this servitude is more terrible than any slavery all together. (Новинар, January 30, 2008)

Men of theatre and cinema proved to be worst affected by the changes, thus transferring their critical attitude from socialism to the working conditions during the transition. The film director Edward Zahariev dedicated his last movie, Late Full Moon (1996), to the transition. The main idea expressed by the leading character is that the power of money has a devastating effect on people and society. Another director, Anry Kulev, also sees mainly shortcomings in the new time (Tpyd, July 17, 2009). The famous theater director from young generation Teddy Moskov joins the criticism too. The assessments of the transition do not express directly the attitude towards socialism, but the comparison is always with the preceding age, which tends to become more attractive.

Actors feel no less affected. Todor Kolev, who was an activist of the UDF at the beginning of the transition, says: "At that time, there was a caste hierarchy that made it impossible to live a normal life. Now, 
another hierarchy appeared and it is as awful as the previous one-the hierarchy led by money" (Tpyd, October 2, 2008). Comedian from the old generation Slavcho Peev notes bitterly: "Actors live poor lives... Everything's about money and there's no end" (Tpyd, January 1, 2009). Momchil Karamitev, the son of the legendary actor Apostol Karamitev who has returned from United States to Bulgaria for a while, looks at things from the side. According to him, "Many things on the free market are developing and there is a private initiative... At the same time, I notice that the intellectual and moral level, in general, is sinking alarmingly" (http://e-vestnik.bg/6432/, June 19, 2009). Mixed feelings about the realities of transition are predominant among actors too and they make them reassess their attitude towards the recent past.

Musicians are another big group of the artistic and creative intelligentsia that has supported the changes on a mass scale in the early 1990s. Twenty five years later, their attitude towards the results of the changes is revised. The conductor Georgi Dimitrov, who has been absent from Bulgaria since the beginning of the transition, exclaims: "When I returned, I realized that nothing of the heritage was continued... Music is not a trade, it's madness... The trouble is that it became a trade in our country" (Kулmypa, January 21, 2005). The jazz singer Camelia Todorova says: "Years ago, art in our country, even under socialism, had an intellectual environment... There's no such environment now. The support which art people in Bulgaria receive from the state today is zero" (ПonApmTpyd, July 18, 2008). According to a very popular pop singer Vasil Naidenov, the comparison between socialism and democracy is not in favour of the latter (Tpyd, July 18, 2008).

Nevertheless, there are intellectuals who keep their negative attitude towards socialism. The writer Georgi Mishev, former member of Communist Party, accuses socialism of the demographic downfall in democratic Bulgaria as well-because of urbanization when millions of peasants "were torn from their natural rural root, deprived of their ownership of the land" (Tpyd, December 20, 2008). In turn, the sociologist Georgi Fotev, formerly a secret agent of State Security, expresses the view of those "on whom the heavy cleaver of the communist regime had landed, people whose life was smashed. They lived in another parallel world, not in the one of privileges" (Tpyd, July 4, 2009). Along with these stands typical of the beginning of the transition, at its end, more and more statements were made concerning the advantages of socialism. Such statements were made by conductor Georgi Dimitrov about high level of Bulgarian choirs, by jazz musician Milcho Leviev (24 yaca, July 20, 2008), by most popular pop singer Lilly Ivanova (Tpyd, April 22, 2009).

\section{Young Bulgarian Generation's Notion of Socialism}

How do the above mentioned factors affect young generation in the formation of their notion of socialism? To answer this question, I will use the results of occasional sociological studies on the attitude towards the recent past and the questionnaires completed by students from St. Kliment Ohridsky University, Sofia.

A comparative study conducted by Mediana Sociological Agency concerning the attitude towards socialism shows that a completely negative attitude towards "the 45 years of socialism" was expressed by $17.7 \%$ in 1990 , while in 2004 - by only $3.6 \%$; fairly negative was the attitude of $42.6 \%$ in 1990 and only of $11.8 \%$ in 2004 , and vice versa - a completely positive attitude towards socialism expressed $2.1 \%$ in 1990 and in 2004 they were $10 \%$, while fairly positive was the attitude of $23 \%$ in 1990 and of $42.2 \%$ in 2004 (Tpyd, September 10, 2004). As shown, the tendency outlined already during the first 15 years of transition. It intensified in the following years - a study of the World Bank in 29 countries in transition from Central and Eastern Europe conducted in 2007 shows that $30 \%$ of the Bulgarians at the age between 18 and 34 years think that life was better under socialism as compared to democracy (Сеza, November 22, 2007). In the next 2008, a far more definite conclusion 
was made in the report on youth: "Socialism has been cleared of its negative remnants and has turned into 'the good old time"' (Tpyd, October 18, 2009). Another study of Mediana shows that an increasing number of young people consider socialism to be "a more humane, more just society, not so free, but people felt better" (Tpyd, October 22, 2008). Interestingly, this statement matches the other one without any problems - that today young people live better than their parents. This is a contradiction but only at first sight because the positive evaluation of socialism has nothing to do with its material characteristics but with its idea of justice. This is the average, i.e., sociological data.

And what is the individual, though not representative, attitude? I will rely on my questionnaires completed by students. In the last three years - from 2007 to 2013 - I held 252 inquiries among students studying different subjects of study (history, international relations, public relations) at three faculties of Sofia University "St. Kliment Ohridski". I asked them several questions, of which the important ones for this case were the questions about the general notion of socialism, of the bad and the good under it. Students' opinions can be summarized as follows.

The greater part of the students answered with the reservation that their notion of socialism was formed in the family - usually from parents but they also mentioned the older generation (first grandfathers and then grandmothers) - and secondly, it was influenced by what they learned at school, while the media were mentioned rarely. Students hardly ever gave a one-sided assessment of socialism — only 18 students expressed a flatly negative attitude towards the whole age and two less -16 persons approved everything under socialism. The collected assessments are not representative but it's worth mentioning that only one fifth of the students gave extreme assessments (22.3\%, of which 11.8 being negative and $10.5 \%$ being positive opinions). The great majority describes socialism as an age full of many problems but also of many advantages.

I will give examples of the two extreme views.

The totally negative notion of socialism is associated with the repressions and restrictions but also with the more generalized notion of what had happened. For example, a four-year history student wrote: "First, I'd like to say that I come from a family, in which there are persons repressed by communists. To a great extent, this fact determines my negative attitude towards those 45 years. I was born in 1986 and I don't have memories of the time of socialism.... Now, being older and already a student, I think that the 45 years, from 1944 to 1989, tore away Bulgarian people from their natural development".

The great number of totally positive notions is associated with the family history too. A student in public relations defined socialism as "one of the best moments in Bulgarian history". I will also cite somewhat of a different opinion. It is of a student of the Master's program in history and reads as follows: "Low crime. More smiling people. Income was not a primary objective (different value system). 97\% of population took a holiday (at the sea). There were no mobile phones, Internet, cable television with 160 channels. Respectively, you had more time for your friends". The important thing for that student is not the material existence but the quality of life.

Students' personal notion of socialism can be seen in the following more striking opinions: "The fairy tale about low prices, easy life and impossible future" (History student), "oranges at Christmas, building of industrial enterprises, waiting for years to get a car, TV shows of pop singers on the New Year's Eve" (International Relations student), "the time of pioneers' camps for at least two weeks in the mountains or at the sea, which was full of both funny and sad stories; control over your work exercised carelessly" (International Relations student), "Many people of my generation rather think that it's better that socialism has gone but for me at least, it was an 'interesting' time, if this is the word, and I do regret, to some extent, that I wasn't able to live under such political system and that I don't have any personal impressions of it" (International Relations student), "Everything was 
one type - one television, one radio station; you're not allowed to listen to music different from Bulgarian and Soviet one" (History student), "My notion of socialism is associated with the equality of people. Everyone had a job and everyone was a specialist in their field. Every man had a home and was a man in society. No difference was made between an ordinary worker and an engineer, for example. Even pupils, irrespective of the financial means of their parents, were equal" (Public Relations student), "A retrogressive system that tried to create equality between 'unequal' people" (International Relations student), "little but for everyone" (History student), "Todor Zhivkov, five-year plans, 'Lada', 'Mraz"' (History student). The notions vary and are composed of both personal memories and what is heard and read.

Students' assessments of the bad things under socialism are not different from those of intellectuals. Most frequently mentioned are: censorship, restrictions on individual freedom ("impossibility to be different"), repressions (the camps and State Security), queues (deficiency), collectivism ("the desire of the ruling class to get people in a matrix"), dependence on the Soviet Union.

There are also absurd accusations such as: "Todor Zhivkov's speeches to be learned by heart", "Skirts above the knees were forbidden", "There was a curfew and, in general, there was a militiaman on the watch at every turn, making sure that you wouldn't do anything immoral", "Prohibition to write with the left hand", "Principles that everything was owned by the state and free of charge".

The positive notions are also typical and repeating. As a rule, social security (the lack of unemployment, the lack of poor people, low prices of goods, electricity and heating), the quality education free of charge for all educational degrees ("I don't know how exactly they taught but older people had learned many things at school") and health care always come first, as much as order and low crime, the chance of advancing in society ("without big income or distinguished or noble ancestors"), as well as the striving for equality ("people were equal", "There were no people with an empty refrigerator and wondering whether they could pay their bills"); a positive aspect of socialism often all too often is morality. And again, as with intellectuals, students regard as positive the state care of cinema, of culture as a whole, of sports, which ensured high achievements. A conclusion made by a student in history combines doubt and approval: "Idealism might have been 'artificial' but at least laid down some standards. People believed in their future”.

The positive assessments of socialism contain some absurd statements too: "Lenin's subbotniks are badly needed even today", "we went to church secretly", "strange as it may seem-the equalization", "higher salaries than now", "the majority of goods was of Bulgarian origin", "uniforms at school, the form of address "Comrade", "the difficulties with acquiring right of residence in Sofia", "brigades", "people had time to visit each other", "people didn't need to think which party to vote for". And the particular personal memories are of the chewing gum "Ideal" at a cost of BGN 0.06, the chocolate "Kuma Lisa" (Br'er Fox), Dyado Mraz (Jack Frost) about New Year, etc.

What do students' notions of socialism point to? They demonstrate the variety of opinions in the modern Bulgarian society - the answers show that variety existed under socialism too, but it was suppressed, hence it prevailed after its collapse. There are two groups among young Bulgarians with opposite evaluations of socialism but they are insignificant (the two of them have some ten per cent adherents). The vast majority of young people regard socialism as a combination between good and bad and this statement is often accompanied by the conclusion, "Socialism in Bulgaria, as any other period of our history, has both positive and negative aspects" (International Relations students). My basic conclusion is that socialism in youth's consciousness is no longer a problem of the present but has become a part of the past. 
In addition, some non-historians are looking for not so specifically historical but rather general definitions of socialism, for example: "For me, socialism is rather an Utopian idea of equality" (International Relations students) or "Good ideas degraded in a bad system" (Public Relations students). The second important conclusion is that in the last years the attitude towards socialism improved considerably, firstly under the influence of the problems of transition. One of the interviewed historians gives an expression of this change: "My parents aren't communists, but lately they began to speak well of socialism as a time of order and security (after 60 years) when there was no such arbitrariness as now".

I think that the third conclusion is very important: Despite of the improved image of socialism, almost no one of the young people wishes it to return. A student is explicit: "For many people today, this is the period of Bulgarian existence when they felt secure; they didn't think what they were going to do with their families tomorrow, but for me, the fact that something in 'the democratic development of Bulgaria went wrong' doesn't mean that I want to experience my mother's school years, not to be allowed to wear jeans, to listen to western music, etc." (Public Relations students). Young Bulgarians live in the new time and use the memory of the good under socialism only as an aspiration for improvement of the democratic existence and as a chance of learning lessons for the future. "Reconciliation" with the past is an important element of the self-confidence of today's Bulgarians, some of whom even deduce from it their idea that they have a certain advantage over their peers from the West. On these lines, I will end with a quotation from the questionnaire form completed by a history student: "We will never know what Bulgaria would look like without socialism but we can learn all the lessons that period gave us and speak about socialism from own experience (or from the experience of our parents) because we lived through it, but we should not judge on it (as other non-socialist countries and people) without having any idea whatever of what 'socialism' is".

\section{Conclusion}

The evolution in the attitude of Bulgarian society to the recent past, as the era of socialism is often called, is a testimony of political normalization. The new political right-wing imperative that dominated the 1990s is replaced by real political pluralism that allows more nuanced attitude towards the past. This is particularly evident in the public positions of well-known Bulgarian intellectuals, but also in the views of Bulgarian students.

But I feel obliged to pay attention also to the latest trends in the recent years. A quarter of a century after the start of the transition sociological surveys show that more than half of the young people born after 1989 have a positive attitude towards socialism and are critical to the current reality. This has led the authorities to undertake a new attack on the socialist past with the hope that this will improve the attitude towards today's life. In other words, the dispute over the socialist past continues to depend on the political imperative. But at least part of the society wants to have the possibility not only to study the socialism period, but also to freely assess the recent past and the results of the transition.

\section{References}

Аврамов, Д. (1994). Летопис на едно драматично десетилетие. Ч. 1 (Chronicle of a Dramatic Decade) (Vol. 1). "Hayка и изкуство", София.

Аврамов, Л. (1993). 50 оспорвани години. Спомени (50 Challenged Years. Meтories). “Захари Стоянов”, София.

Ангелов, П., Георгиева, Ц., Бакалов, Г., \& Цанев, Д. (1992). Записки по история на България 681-1878 (Notes on History of Bulgaria 681-1878). “Булвест”, София. 
Baeva, I. (2006). The year of the Palace Coup or a new start in Bulgarian history. Miscellanea Bulgarica, 18, 45-52.

Бобев, Б. (1992). Записки по история на България. 1878-1944 (Notes on History of Bulgaria 1878-1944). “Булвест”, София.

Бонев, С. (2001). Времето в което живях и хората с които работих (The Time I Lived in and the People I Worked With). "Нови хоризонти", София.

Бончева, Е и др. съст. (1991). Българският ГУЛАГ. Свидетели (Bulgarian GULLAG. Witnesses). “Демокрация”, София.

Бочев, Ст. (1990). Белене. Сказание за конилагерна България (Belene. Testimony for Concentration Camp Bulgaria). Фондация “Българска култура и наука”, София.

Василев, Г. (1995). Остров Персин. Позорът на България (Persin Island. The Shame of Bulgaria). “Св. Кл. Охридски”, София.

Венедиков, И. (1993). Познайте ги по делата им. Българската интелигенция в моите спомени (Guеss Them in Their Deeds. The Bulgarian Intelligentsia in My Memories). “Христо Ботев”, София.

Свинтила, В. (1992). Лицето на Голготата. В полицейската психиатрия (The Face of the Golgotha. In Police Psychiatry). “Изток-Запад”, София.

Семерджиев, А. (1999). Прежсияното не подлежи на обжалване (The Experience Is Subject to No Appeal). “Христо Ботев”, София.

Семков, М. (1992). Записки по съвременна история (Notes on Contemporary History). “Св. Георги Победоносец”, София.

Солаков, А. (1993). Председателят на КДС разказва... (The Chairman of the State Security Talks...) “Тексимреклама” АД, София.

Гаук, Й., Яковлев, А., Малиа, М., Лаар, М., Шарланов, Д., Огнянов, Л., Цветков, П., Рушан, Р., Нойберт, Е., Янакакис, И., \& Байе, Ф. (2004). Черната книга на комунизма. Ч. 2 (The Black Book of Communism) (Vol. 2). “Прозорец”, София.

Генов, И. (1993). Съдбата на жертвите. Народния съд в Бургас. Бургас (The Destiny of the Victims. The People's Court in Burgas).

Гешев, Н. (1992). Белене-островът на забравените (Belene-The Island of Forgotten). “Завръщане”, София.

Гюзелев, В., Косев, К., Лалков, М., Огнянов, Л., \& Радева, М. (2001). История за 11 клас (The History for 11th Grade). "Просвета", София.

Делев, П., Ангелов, П., Бакалов, Г., Георгиева, Ц., Митев, П., Трифонов, С., Баева, И., Василева, Б., \& Калинова, Е. (2001). История за 11 клас (The History for 11th Grade). “Отворено общество”, София.

Дертлиев, П. (1996). Ден първи-ден последен (Day First—Day Last). “Свят-Наука”, София.

Живков, Ж. (1991). Кръглата маса на политбюро. ХVI-та република. Случаят Кремиковци. Разгромът на “Тексим”, Чехословашките събития. Крах на едноличната власт (The Round Table of Politburo. 16th Republic. Kremikovci Case. The Defeat of "Teksim”, The Prague Spring, The End of Authoritarian Power). "Интерпрес 67”, София.

Живков, Т. (1993). Срещу някои лъжи (Against Some Lias). “Делфин прес”, София.

Иванов, Д. (1994). Противопоставянето 1956-1989 (Opposition 1956-1989). “Арес прес”, София.

Минков, И. (1990). “Слънчев бряг”, лагерът на смъртта (“Sunny Beach”, the Caтp of Death). “БЗНС”, София.

Мирчева, Х., Найденов, Ч., \& Баева, И. (1991). История за 9 клас (The History for 9th Grade). "Просвета”, София.

Михайлов, Ст. (1993). Живковизмът през призмата на една лична драма (The Zhivkov's Power Through the Prism of a Personal Drama). "М-8-М”, София.

Огойски, П. (1995). Записки за българските страдания 1944-1989 2. Кн. 1 и 2 (Notes for Bulgarian Passions 1944-1989) (Vol. 1 and 2). “Феномен”, София.

Петков, П. (1992; 1993). Записки по история на новото време (Notes on Modern History). Ч. 1 и 2, “Свят-Наука”, София.

Тодоров, Ст. (1995). До върховете на властта (To the Top of the Power). “Захари Стоянов”, София.

Тодоров, Цв. (1998). На чужда земя (On a Foreign Land). “Отворено общество”, София.

Трайков, Б. (1999). 10 ноември 1989. Превратът (10th of November-The Palace Coup 1989). “Труд”, София.

Трифонов, С. (1991). История на България 1878/1944 г (The History of Bulgaria). "Просвета”, София.

Фол, А., Мутафчиева, В., Гаврилова, Р., \& Илчев, И. (2001). История за 11 клас (The History for 11th Grade). “Анубис”, София.

Христов, Д. (1991). Пред истински демократичен съд бих се оправдал. Мемоари на министъра на вътрешните работи (In Front of a Genuine Democratic Court, I Would Be Justified. Memoirs of the Minister of the Interior). “Инграф”, София.

Чакъров, К. (1990). Вторият етаж (The Second Floor). “К \& М” София.

Чакьров, К. (2001). От втория етаж към нашествието на демократите (From the Second Floor to the Invasion of the Democrats). “Труд”, София. 